\title{
HEALTH-AFFECTING METHYL-DONOR COMPOUNDS IN SOUR CHERRY (PRUNUS CERASUS L.) FRUIT PARTS IN THE FRUIT BURGEONING STAGE
}

\author{
S. SZÜGYI* and É. SÁRDI ${ }^{\mathrm{b}}$ \\ ${ }^{a}$ Fruitculture Research Institute, National Agricultural Research and Innovation Centre, \\ H-1223 Budapest, Park u. 2. Hungary \\ bepartment of Genetics and Plant Breeding, Faculty of Horticulture, Szent István University, H-1118 Budapest, \\ Villányi út 29-43. Hungary
}

(Received: 12 August 2017; accepted: 7 December 2017)

\begin{abstract}
In recent years, numerous studies have confirmed the vital role and therapeutic potential of quaternary ammonium compounds and endogenous formaldehyde in the prevention and treatment of diseases. These compounds participate in the transmethylation processes and play a role in the metabolism and in the regulation of cellular processes. The present research indicates that sour cherry fruit contains large quantities of quaternary ammonium compounds in the early developmental phase (burgeoning). The quantity of methyl-donor compounds (choline, carnitine) and easily mobilizable methyl groups were measured in various fruit parts (stalk, fruit flesh, seed kernel) of five sour cherry cultivars using OPLC technology, and the cultivar dependence of the detected compounds was examined. The results of comparative examinations established the presence of choline in the stalk and seed and of a significant amount of carnitine in the fruit flesh. The clear, significant differences between the genotypes will facilitate the selection of cultivars containing the largest proportion of components beneficial for human health.
\end{abstract}

Keywords: sour cherry, choline, HCHO, carnitine, OPLC evaluation

Sour cherries are very important dietary sources of vitamins and polyphenols. Most studies focus on the antioxidant properties of the polyphenol components (SASS-Kiss et al., 2005). High anthocyanin content has beneficial effect in the case of obesity, inflammatory processes, hyperlipidaemia, type 2 diabetes, and cardiovascular diseases (FORD \& MOKDAD, 2001; SEymour et al., 2009). Sour cherry stalks have long been used as an infusion or tea, but compared to the fruit, relatively little information is available regarding the composition and bioactive properties (BASTOS et al., 2015). Based on previous studies, sour cherry stalks make an excellent diuretic (Hooman et al., 2009) and, due to its natural antioxidant (polyphenol) content, can also be used as a detoxicant (Bursal et al., 2013). The extract of sour cherry seed kernel is rich in flavin, flavonoid, and trans-resveratrol that have protective effects in the cardiovascular system (BAK et al., 2006). The oil of seed kernel contains unsaturated fatty acids, oleic acids, $\alpha$-tocopherol, and tocopherol like components. The combined effect of these compounds is expected to make sour cherry seed kernel oil a valuable dietary supplement (BAK et al., 2010).

In woody plants, compounds participating in transmethylation processes, such as endogenous formaldehyde ( $\mathrm{HCHO}$ ) and quaternary ammonium compounds, have been the subject of less research, though their role in the biotic and abiotic stress tolerance of plants has been demonstrated (Gopal et al., 1990; SÁrdi \& TYiHÁk, 1998; Nuccio et al., 2001). In transmethylation reactions, S-adenosyl-L-methionine (SAM) is the "methyl donor", and the

* To whom correspondence should be addressed.

Phone: +36 30 4067466; e-mail: szugyisandor4@gmail.com 
methyl group of SAM reaches the acceptor molecules through the formation of $\mathrm{HCHO}$ as an intermediate product (HuszTI \& ТYнHÁK, 1986). HCHO precursors (generators, methyl donors) are connected directly or indirectly to the methylation cycle, in which nucleic acids, proteins, peptides, amino acids, biogenic amines, nor-alkaloids, etc. may be involved as acceptor molecules. Transmethylation, i.e. the removal or integration of methyl groups, is a low-energy, fast substitution reaction allowing reversible regulation. The reversible reactions influence the weight, hydrophobicity, and solubility of molecules, thereby affecting their function and enzyme activity (NÉMETH, 2002). The "HCHO" denomination means those methyl or oxidised methyl groups in the biological systems from which potentially $\mathrm{HCHO}$ may arise.

Recent research shows that HCHO plays a key role in the antibiotic effects (BURKE \& $\mathrm{KocH}, 2001)$ and may fulfil an essential function in regulating the balance between cell division and cell death, where a defect may lead to diseases through abnormal cell proliferation (TYннÁK et al., 2001). The role of methyl-donor compounds (primarily choline and betaine) in the metabolism and in the regulation of cellular processes has been proved from various aspects (Niculescu \& Zeisel, 2002; Mudd et al., 2007; Kotsopoulos et al., 2010; Corbin \& ZeISEL, 2012).

On the one hand, choline inhibits cholesterol accumulation and facilitates metabolism, the utilization of fatty acids, and the detoxification of the body; on the other hand, during brain metabolism, it transmutes into acetylcholine, which participates in signal transduction and in the regulation of the functions of nerves coordinating muscle movement (Yовнімото et al., 2004). As phosphatidylcholine, it preserves the integrity of the cell membrane, participates in intracellular communication, in the transmission of information, and in the energy supply of cells (VIVEKANANDA et al., 2000). Based on research by ZEISEL and coworkers (2003), the most significant food products containing choline are animal source foods. Among plant source foods, seeds or young plant parts are worth mentioning.

Carnitine (L-carnitine) plays a critical role in intracellular and metabolic functions, such as the transportation of fatty acids to the mitochondria, the stabilization of cell membranes, and the reduction of serum lipid levels. L-carnitine supplement has proved to be advantageous in the case of obesity, type 2 diabetes, and liver cirrhosis (Del Ben et al., 2016). The best sources of carnitine are animal source foods. Vegetables have significantly lower carnitine content and fruit even lower (KNÜTTEL-GuSTAVSEN \& HARMEYER, 2007).

Lack of methyl-donor compounds alters DNA methylation, and thus gene expression (ZEISEL, 2012). Abnormal DNA methylation can often be found in cancer cells and may be associated with chromosome instability and the inactivity of tumour-inhibiting genes (DAVIS \& UTHUs, 2004). The objective of the present experiments was thus to examine compounds participating in endogenous transmethylation processes in different plant parts of sour cherry fruit at a young developmental stage (in spring). The research focused primarily on the comparison of cultivars based on the nutritional and human-health-related significance of quaternary ammonium compounds.

\section{Materials and methods}

\subsection{Plant material}

The sour cherry cultivars 'Érdi bőtermő', 'Csengődi', 'Pipacs 1', 'Kántorjánosi', and 'Újfehértói fürtös' were obtained from the Fruitculture Research Institute of the National 
Agricultural Research and Innovation Centre. The samples were collected from a commercial orchard. The trees were grafted on Mahaleb rootstock and were spaced $5 \mathrm{~m}$ apart in the row, with $7 \mathrm{~m}$ between rows. The samplings were performed in 2017 in five repetitions. One repetition was prepared by homogenising 15 samples from each fruit part. The fruit were pitted, all flesh and stem were used for analysis. The endocarps of the seeds were removed, and only the kernels were used for analysis. The determination of the optimal times of fruit burgeoning was based on the method elaborated by SzABÓ (2007). All fruit samples (stalk, fruit flesh, and seed kernel) were collected in the same burgeoning state, i.e. when the fruit turn from green to yellowish green.

\subsection{Chemicals and OPLC evaluation}

The chemicals $\left(\mathrm{N}^{\varepsilon}\right.$-trimethyl-lysine, carnitine, choline, trigonelline, betaine, dimedone, and sodium acetate) were of HPLC grade and were purchased from Sigma-Aldrich Ltd. (Budapest, Hungary). All solvents (methanol, chloroform, methylene chloride, and $i$-propanol) were of HPLC grade and were purchased from Merck Ltd. (Budapest, Hungary).

The OPLC (Overpressured Layer Chromatographic Separation) technique and densitometry evaluation (developed by OPLC-NIT Co., Ltd., Budapest, Hungary) were used for the quantitative and qualitative determination of quaternary ammonium compounds and endogenous formaldehyde. Tissue samples of fruit parts were frozen in liquid nitrogen, powdered, and extracted with dimedone solution (500 $\mathrm{mg}$ tissue powder in $800 \mathrm{ml}$ of $0.03 \%$ methanolic dimedone solution). After $10 \mathrm{~min}$ of ultrasonic cleaning (Titertek Ultrasonic Cleaner), the suspension was centrifuged (ScanSpeed Mini) at $1000 \mathrm{~g}$ for $10 \mathrm{~min}$ at room temperature. The clear supernatants were used for OPLC separation on silica gel plates (Kieselgel $60 \mathrm{~F}_{254}$ ). The mixture of quaternary ammonium compounds used as standard contained $\mathrm{N}^{\varepsilon}$-trimethyl-lysine (TML), carnitine, choline, trigonelline (TGL), and betaine. The OPLC separations were carried out using chloroform - methylene chloride $(\mathrm{v} / \mathrm{v}=35: 65)$ for formaldemethone determination and $i$-propanol - methanol $-0.1 \mathrm{M}$ sodium acetate $(\mathrm{v} /$ $\mathrm{v}=20: 3: 30$ ) for quaternary ammonium compounds. After development, the formaldemethone and quaternary ammonium compound spots were evaluated using a Shimadzu CS-930 TLC/ HPTLC scanner at $\lambda=265 \mathrm{~nm}$ for formaldemethone and at $\lambda=525 \mathrm{~nm}$ for quaternary ammonium compounds using, in this case, Dragendorff reagent (SÁrdI \& TYıHÁK, 1998).

\subsection{Determination of dry matter content}

From each homogenised fruit sample $5 \mathrm{~g}$ was oven-dried at $105^{\circ} \mathrm{C}$ to constant weight, and the dry matter content was calculated from the weight loss.

\subsection{Statistical analysis}

Data were analysed using the ANOVA model and means comparison, and significant differences were calculated using Duncan's multiple range test $(\mathrm{P}=0.05)$. Five repetitions were run in all three methods of testing (stem, fruit flesh, and seed kernel) in 2017. The correlations were analysed by Spearman's rank order correlation $(\mathrm{P}=0.01$ and $\mathrm{P}=0.05)$. Statistical analysis was carried out using the 22.0 software (SPSS Inc., Chicago, USA). 


\section{Results and discussion}

Among the quaternary ammonium compounds occurring in the standard used for identification under the given measuring circumstances, choline was reproducibly measurable at this developmental stage in the seeds and stalks and carnitine in the fruit flesh.

The quantities of detectable methyl-donor compounds depended on the plant part and were significantly dependent on the cultivar. The quantities of endogenous HCHO and methyl-donor choline showed the least variability in the seed (Fig. 1), where the choline levels were about five times that detected in the stalk (Fig. 2).

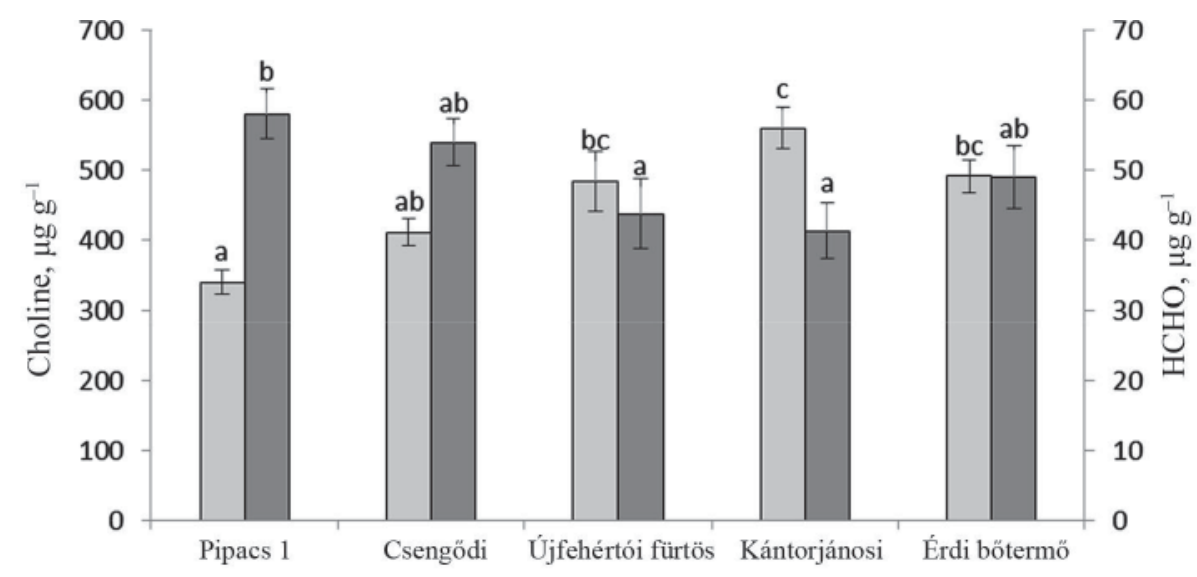

Fig. 1. Choline and endogenous HCHO contents in the seed kernels (Mean values with different letters are significantly different at $\mathrm{P}=0.05)$. $\square$ : Choline; $\square$ : $\mathrm{HCHO}$

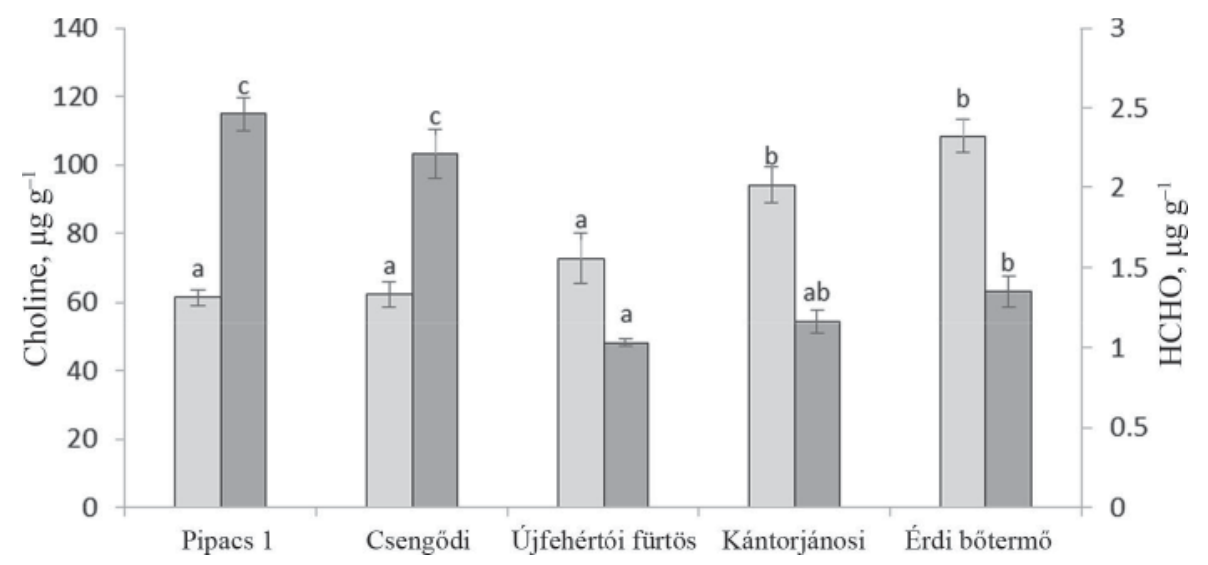

Fig. 2. Choline and endogenous $\mathrm{HCHO}$ contents in the stalks (Mean values with different letters are significantly different at the $\mathrm{P}=0.05)$. $\square$ : Choline; $\square$ : $\mathrm{HCHO}$ 
Significant differences could also be seen in the HCHO quantities, which were again dependent on plant part and genotype. There was a negative correlation between the choline and $\mathrm{HCHO}$ contents: cultivars with higher choline contents contain smaller amounts of "bound" HCHO than those with lower choline contents. However, a statistically verifiable negative correlation between choline and HCHO could only be established in the seed kernel, $\mathrm{R}^{2}=0.9006$ (Fig. 3). A negative correlation between choline and $\mathrm{HCHO}$ was also observed in the fruit stalk, but the correlation was not significant, so further examinations will be needed before conclusions can be drawn.

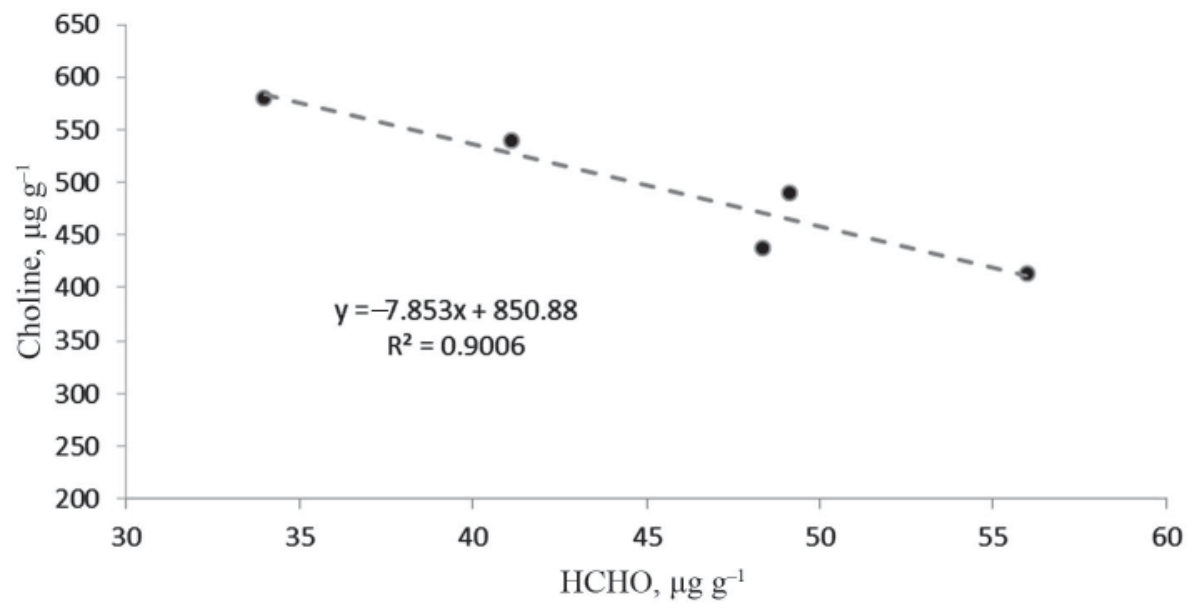

Fig. 3. Correlation between the average choline and $\mathrm{HCHO}$ quantities in the seed kernel $(\mathrm{P}=0.01)$

Surprisingly high quantities of carnitine were detected in the fruit flesh, but considerable cultivar dependence was again observed. With the exception of one cultivar ('Érdi bőtermő'), higher carnitine contents were associated with lower "bound" HCHO quantities (Fig. 4). The negative correlation was statistically verifiable, $\mathrm{R}^{2}=0.6131$ (Fig. 5).

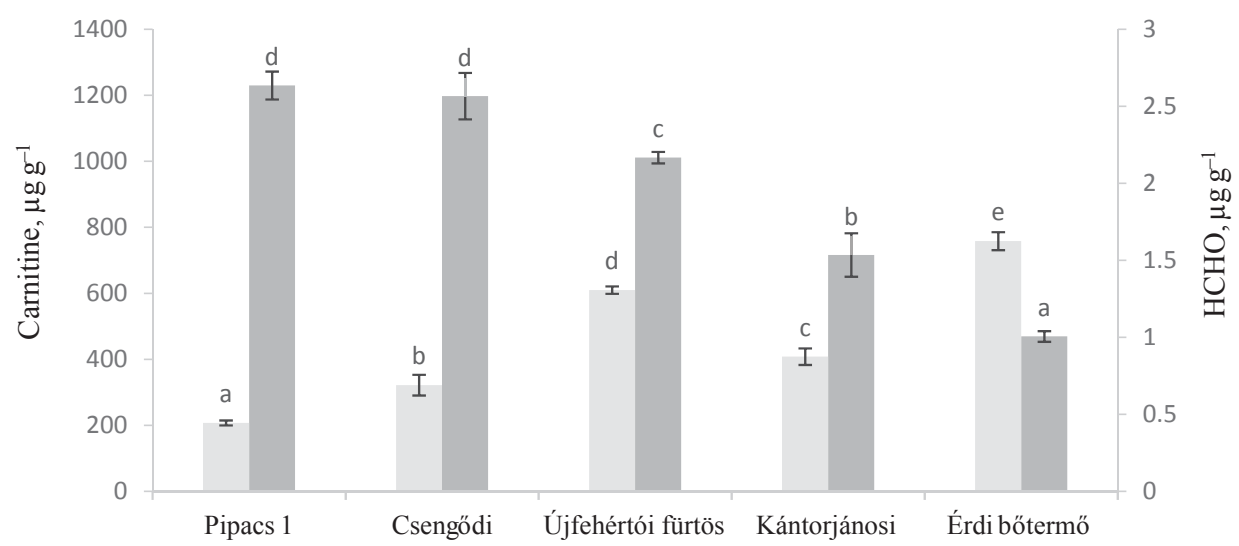

Fig. 4. Carnitine and endogenous HCHO contents in the fruit flesh (Mean values with the different letters are significantly different at $\mathrm{P}=0.05) \square$ : Carnitine; : $\mathrm{HCHO}$ 


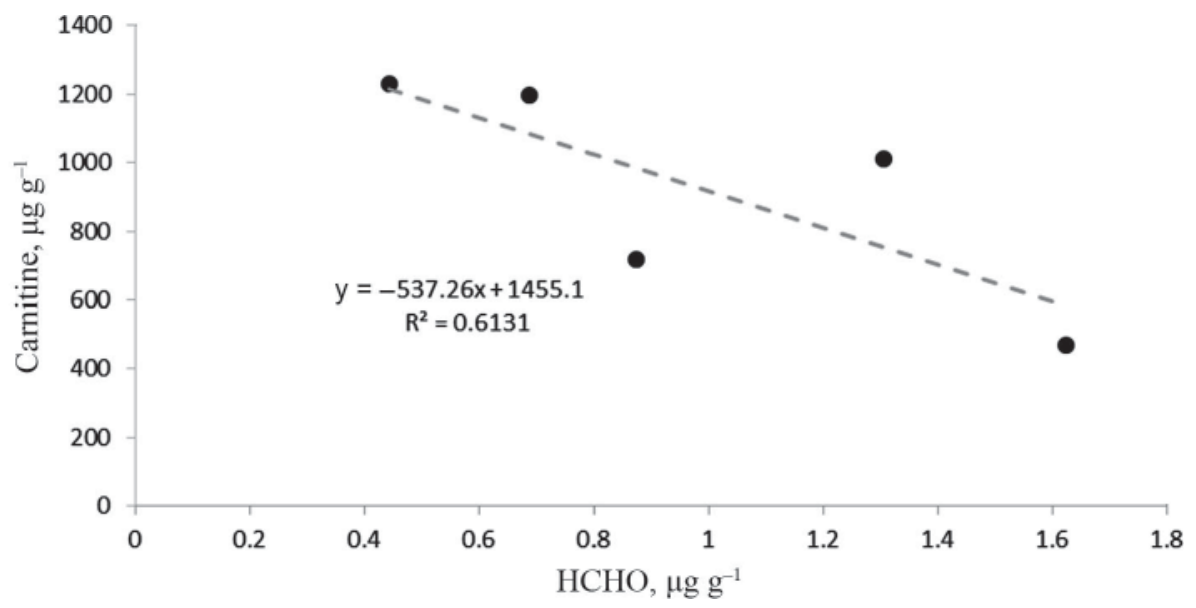

Fig. 5. Correlation between the average quantities of carnitine and $\mathrm{HCHO}$ in the fruit flesh $(\mathrm{P}=0.05)$

On the basis of dry matter content, the quantities of methyl-donor compounds were converted into dry weight in order to determine the chemical quality of the fruit parts as possible components of dried or lyophilised products (Table 1).

Table 1. Quantities of methyl-donor compounds and HCHO in terms of dry mass in specific fruit parts

\begin{tabular}{|c|c|c|c|c|c|c|}
\hline \multirow{3}{*}{$\begin{array}{l}\text { Fruit part } \\
\text { Cultivar }\end{array}$} & \multicolumn{2}{|c|}{ Seed kernel } & \multicolumn{2}{|c|}{ Stalk } & \multicolumn{2}{|c|}{ Fruit flesh } \\
\hline & \multicolumn{2}{|c|}{ dry mass, $\mu \mathrm{g} \mathrm{g}^{-1}$} & \multicolumn{2}{|c|}{ dry mass, $\mu \mathrm{g} \mathrm{g}^{-1}$} & \multicolumn{2}{|c|}{ dry mass $\mu \mathrm{g} \mathrm{g}^{-1}$} \\
\hline & $\mathrm{HCHO}$ & Choline & $\mathrm{HCHO}$ & Choline & $\mathrm{HCHO}$ & Carnitine \\
\hline Pipacs 1 & $54.8 \pm 16.8 \mathrm{a}$ & $937 \pm 135.6 \mathrm{~b}$ & $1.4 \pm 0.3 \mathrm{a}$ & $119.2 \pm 23.2 \mathrm{~b}$ & $0.5 \pm 0.1 \mathrm{a}$ & $1375.8 \pm 103.1 \mathrm{~d}$ \\
\hline Csengődi & $68.5 \pm 13.6 \mathrm{ab}$ & $898.8 \pm 67.1 \mathrm{ab}$ & $1.4 \pm 0.3 \mathrm{a}$ & $106.6 \pm 11 \mathrm{~b}$ & $0.7 \pm 0.3 \mathrm{a}$ & $1298.7 \pm 110 \mathrm{~d}$ \\
\hline Újfehértói fürtös & $83.9 \pm 16 b c$ & $758.5 \pm 224.6 \mathrm{ab}$ & $1.6 \pm 0.4 \mathrm{ab}$ & $49.9 \pm 9.2 \mathrm{a}$ & $1.5 \pm 0.5 \mathrm{~b}$ & $1128.9 \pm 125.2 \mathrm{c}$ \\
\hline Kántorjánosi & $95.9 \pm 26.8 \mathrm{c}$ & $707.8 \pm 166 \mathrm{a}$ & $2.1 \pm 0.6 \mathrm{bc}$ & $56.1 \pm 7.8 \mathrm{a}$ & $0.9 \pm 0.4 \mathrm{a}$ & $776 \pm 157.7 \mathrm{~b}$ \\
\hline Érdi bőtermő & $78.1 \pm 20.6 \mathrm{abc}$ & $778.4 \pm 117.9 \mathrm{ab}$ & $2.4 \pm 0.9 \mathrm{c}$ & $65.1 \pm 13.7 \mathrm{a}$ & $1.7 \pm 0.4$ & $502.4 \pm 162.6 \mathrm{a}$ \\
\hline
\end{tabular}

a,b,c: Mean values followed by different letters are significantly different at $\mathrm{P}=0.05$

At present, primarily in the field of medical sciences, increasing attention is being paid to the physiological effects of endogenous transmethylation and the methyl-donor compounds participating in the methylation cycle, as well as to the study of their role in the human metabolism, in its regulation, and in the control of various gene functions (CorBIN \& ZeIseL, 2012). Methylation defects are demonstrably linked to an increased risk of numerous diseases (including tumorous diseases). Knowledge of the connection between defects in methylation and demethylation processes and the development of various diseases will enable us to influence and, if necessary, to normalize the "available" methyl pool of the body in order to preserve or, in the case of destabilization, to restore the methyl balance (TiRABOSCHI et al., 2004; DeL BEN et al., 2016). This question can be approached through chemical-biochemical 
means and via natural resources and nutrition (SÁRDI et al., 2009; BLÁzovics et al., 2012). The quantitative dependence of $\mathrm{HCHO}$ and methyl-donor compounds on the age and development of the plant part was previously verified in the case of watermelon (SÁRDI \& TYIHÁK, 1998) and bean plants (SÁrdi \& STEFAnovits-BánYaI, 2006), larger quantities being observed in younger plant parts than in older ones. The early developmental stage was chosen, because the main purpose was to find plant sources rich in methyl-donor compounds. The quantities of these compounds showed significant cultivar dependence even at the early burgeoning stage and were also significantly influenced by the plan part. A considerable amount of choline was detected in the seeds and high concentrations of carnitine in the fruit flesh.

The average carnitine content in the fruit flesh of the sour cherry genotypes was 91.8 $\mathrm{mg} / 100 \mathrm{~g}$ of fresh mass and $101.6 \mathrm{mg} / 100 \mathrm{~g}$ of dry mass, considerably exceeding the published data for the plants (KNÜTTEL-Gustavsen \& HarmeYer, 2007). The average choline content in the seed kernels of burgeoning sour cherry fruit was $49.2 \mathrm{mg} / 100 \mathrm{~g}$ of fresh mass and $81.6 \mathrm{mg} / 100 \mathrm{~g}$ of dry mass, which, based on data in the literature (Zeisel et al., 2003), could make them a good plant source for choline. The average choline content of the stalk was $7.68 \mathrm{mg} / 100 \mathrm{~g}$ of fresh mass and $7.95 \mathrm{mg} / 100 \mathrm{~g}$ of dry mass, which could contribute to its well-known health benefits.

\section{Conclusions}

The results confirm that, by systematically extending the range of plant species examined, it is possible to find new sources of compounds with proved role in human health preservation. The consumption of biologically active compounds of natural origin is less likely to lead to dangerous overdoses than that of synthetic compounds currently available, further emphasising the benefit of natural sources. Because the plants' methyl donor pool is a less researched area, our examination may give new information in the case of any plant origin food recommended for consumption. If the seeds are to be used as food supplement, it is important to examine not only beneficial components, but also possible harmful compounds, such as amygdaline, which occurs in various quantities in drupes and whose beneficial or harmful effect is very controversial (PARK et al., 2005; MiLAzzo et al., 2007).

This work was funded by the National Agricultural Research and Innovation Centre, Hungary, R\&D Project No. GD003, GD004/2017.

\section{References}

Bak, I., Lekli, I., Juhasz, B., Varga, E., Varadi, J., Gesztely, R., Szabo, G., Szendrei, L., Bacskay, I., Vecsernyes, M., Antal, M., Fesus, L., Boucher, F., Leiris, J. \& Tosaki, A. (2006): Cardioprotective mechanisms of Prunus cerasus (sour cherry) seed extract against ischemia-reperfusion-induced damage in isolated rat hearts. Am. J. Physiol. Heart C., 291, 1329-1336.

Bak, I., Lekli, I., Juhasz, B., Varga, E., Varga, B., Gesztelyi, R., Szendrei, L. \& Tosaki, A. (2010): Isolation and analysis of bioactive constituents of sour cherry (Prunus avium) seed kernel: an emerging functional food. $J$. Med. Food, 13, 905-910. 
Bastos, C., Barros, L., Duenas, M., Calhelha, R.C., Queiroz, M.J.R.P., Santos-Buelga, C. \& Ferreira, I.C.F.R. (2015): Chemical characterisation and bioactive properties of Prunus avium L.: The widely studied fruits and the unexplored stems. Food Chem., 173, 1045-1053.

Blázovics, A., NyirÁdy, P., Romics, I., Szücs, M., Horváth, A., Szilvás, Á., Székely, E., Szentmihályi, K., Bekő, G. \& SÁRDI, É. (2012): How can cancer-associated anemia be moderated with nutritional factors and how do Beta vulgaris L. ssp. esculenta var. rubra modify the transmethylation reaction in erythrocytes in cancerous patients? -in: Silverberg, D.S (Ed.) Anemia. InTech Open Access Publisher, Rijeka. pp. 93-114.

Burke, P.J. \& Косн, T.H. (2001): Doxorubicin-formaldehyde conjugate, doxoform: induction of apoptosis relative to doxorubicin. Anticancer Res., 21, 2753-2760.

Bursal, E., KöKsal, E., Gülcin, I., Bilsel, G. \& Gören, A.C. (2013): Antioxidant activity and polyphenol content of cherry stem (Cerasus avium L.) determined by LC-MS/MS. Food Res. Int., 51, 66-74.

Corbin, K.D. \& Zeisel, S.H. (2012): Choline metabolism provides novel insights into non-alcoholic fatty liver disease and its progression. Curr. Opin. Gastroen., 28, 159-165.

Davis, C.D. \& Uthus, E.O. (2004): DNA methylation, cancer susceptibility, and nutrient interactions. Exp. Biol. Med., 229, 988-995.

Del Ben, M., Polimeni, L., Baratta, F., Pastori, D. \& Angelico, F. (2016): The role of nutraceuticals for the treatment of non-alcoholic fatty liver disease. Brit. J. Clin. Pharmaco., 83, 88-95.

Ford, E.S. \& Mokdad, A.H. (2001): Fruit and vegetable consumption and diabetes mellitus incidence among U.S. adults. Prev. Med., 32, 33-39.

Gopal, D.V.R.S., Sreenivasulu, P. \& Nayudu, M.V. (1990): Effect of Bavistin on lipid metabolism in groundnut (Arachis hypogaea L.) leaves infected with peanut green mosaic virus (PGMV). Physiol. Mol. Plant. P., 37, $1-8$.

Hooman, N., Mojab, F., Nickavar, B. \& Pouryousefi-Kermanni, P. (2009): Diuretic effect of powdered Cerasus avium (cherry) tails on healthy volunteers. Pak. J. Pharm. Sci., 22, 381-383.

HuszTi, S. \& TYiнÁK, E. (1986): Formation of formaldehyde from S-adenosyl-L- (methyl-3H) methionine during enzymic transmethylation of histamine. FEBS Letters, 209, 362.

KnÜttel-Gustavsen, S. \& Harmeyer, J. (2007): The determination of L-carnitine in several food samples. Food Chem., 105, 793-804.

Kotsopoulos, J., Hankinson, S.E. \& Tworoger, S.S. (2010): Dietary betaine and choline intake are not associated with risk of epithelial ovarian cancer. Eur. J. Clin. Nutr., 64, 111-114.

Milazzo, S., Lejeune, S. \& ERnst, E. (2007): Laetrile for cancer: A systematic review of the clinical evidence. Support Care Cancer, 15, 583-595.

Mudd, S.H., Brosnan, J.T., Brosnan, M.E., Jacobs, R.L., Stabler, S.P., Allen, R.H., Vance, D.E. \& Wagner, C. (2007): Methyl balance and transmethylation fluxes in humans. Am. J. Clin. Nutr., 85, 19-25.

NÉMETH, Zs.I. (2002): A formaldehid és természetes generátorai, mint a környezeti hatások jelzö molekulái a csertölgy ontogenezisének korai szakaszaiban. (Formaldehyde and its natural generators as marker molecules of environmental effects in the early ontogenesis of European turkey oak). Dissertation, University of West Hungary, 8 .

Niculescu, M.D. \& Zeisel, S.H. (2002): Diet, methyl donors and DNA methylation: interactions between dietary folate, methionine and choline. J. Nutr., 132, 2333S-2335S.

Nuccio, M.L., Russell, L.B., Nolte, K.D., Rathinasabapathi, B., Gage, D.A. \& Hanson, A.D. (2001): The endogenous choline supply limits glycine betaine synthesis in transgenic tobacco expressing choline monooxygenase. Plant J., 16, 487-496.

Park, H.J., Yoon, S.H., Han, L.S., Zheng, L.T., Jung, K.H., Uhm, Y.K., Lee, J.H., Jeong, J.S., Joo, W.S., Yim, S.V., Chung, J.H. \& Hong, S.P. (2005): Amygdaline inhibits genes related to cell cycle in SNU-C4 human colon cancer cells. World J. Gastroentero., 11, 5156-5161.

SÁrdi, É. \& Stefanovits-BÁnyai, É. (2006): Relationship between peroxidase activity and the amount of fully $\mathrm{N}$-methylated compounds in bean plants infected by Pseudomonas savastanoi pv. Phaseolicola. Acta Phyisiol. Plant., 28, 523-528.

Sárdi, É., Stefanovits-Bányai, É., Kocsis, I., Takács-Hájos, M., Fébel, H. \& Blázovics, A. (2009): Effect of bioactive compounds of table beet cultivars on alimentary induced fatty livers of rats. Acta Alimentaria, 38 , $267-280$.

SÁRDI, É. \& TYIHÁK, E. (1998): Change of biotransformation steps of formaldehyde cycle in water-melon plants after infection with Fusarium oxysporum. Acta Biol. Hung., 49, 353-362.

Sass-Kiss, A., Kiss, J., Milotay, P., Kerek, M.M. \& Tóth-Markus, M. (2005): Differences in anthocyanin and carotenoid content of fruits and vegetables. Food Res. Int., 38, 1023-1029. 
Seymour, E.M., Lewis, S.K., Urcuyo-Llanes, D.E., Tanone, I.I., Kirakosyan, A., Kaufman, P.B. \& Bolling, S.F. (2009): Regular tart cherry intake alters abdominal adiposity, adipose gene transcription, and inflammation in obesity-prone rats fed a high fat diet. J. Med. Food, 12, 935-942.

Szabó, T. (2007): Az északkelet-magyarországi meggy tájfajta szelekció eredményei és gazdasági jelentösége (Results and economic importance of the North Eastern Hungarian sour cherry landrace cultivar selection). Dissertation, Corvinus University of Budapest, p. 46.

Tiraboschi, P., Sabbagh, M.N., Hansen, L.A., Salmon, D.P., Merdes, A., Gamst, A., Masliah, E., Alford, M., Thal, L.J. \& Corey-Bloom, J. (2004): Alzheimer disease without neocortical neurofibrillary tangles: "a second look". Neurology, 62, 1141-1147.

TyıнÁk, E., Bocsi, J., TímÁR, F., RÁcz, G. \& Szende, B. (2001): Formaldehyde promotes and inhibits the proliferation of cultured tumour and endothelial cells. Cell Proliferat., 34, 135-141.

Vivekananda, J., Awasthi, V., Awasthi, S., Smith, D.B. \& King, R.J. (2000): Hepatocyte growth factor is elevated in chronic lung injury and inhibits surfactant metabolism. Am. J. Physiol. Lung C., 278, 382-392

Yoshimoto, M., Waki, A., Obata, A., Furukawa, T., Yonekura, Y., Fujibayashi, Y., Chang, J.C., Gross, E.A. \& BARRow, S.C. (2004): Radiolabeled choline as a proliferation marker: Comparison with radiolabeled acetate. Nucl. Med. Biol., 31, 859-865.

Zeisel, S.H., Mar, M.H., Howe, J.C. \& Holden, J.M. (2003): Concentrations of choline-containing compounds and betaine in common foods. J. Nutr., 133, 1302-1307.

ZEISEL, S.H. (2012): Dietary choline deficiency causes DNA strand breaks and alters epigenetic marks on DNA and histones. Mutat. Res., 733, 34-38. 